\title{
・研究童紹介
}

\section{東京理科大学理工学部土木工学科 土木計画学研究室（大林研究室）}

\section{大林 成行}

はじめに

東京理科大学は, 明治 14 年 6 月東京物理学講習所 (明 治 16 年 9 月東京物理学校と改称）として創立されて以 来，「理学の普及を以て国運発展の基礎とする」との理 想を揭げ，109 年の永きにわたり歩み続けている．昭和 24 年 4 月の学制改革により東京理科大学となり, 現在, 理, 薬, 工, 理工, 基礎工学部といった 5 つの学部が設 置されている. わが国でも特色のある理科系の総合大学 として理学および科学技術の教育, 普及, 発展に寄与し てきた。また，社会の高度化，多様化に対応するために 学部間にわたって専門研究を行う東京理科大学総合研究 所 (6 研究部門) を有している. 理工学部土木工学科は, 昭和 50 年 4 月 1 日に丸安隆和教授, 福岡正巳教授の赴 任により開設され，本学の歴史の中にあって新しい学科 として注目を浴びることとなった. 1990 年 4 月現在ま でに 12 期の卒業生を社会に送り出している. 私立大学 の特色として講座制は認められていないが，土木計画学 を担当する研究室は「大林研究室」として大林成行教授 のもと, 土木計画学, 国土情報処理工学, リモートセン シング特論および演習等, 土木工学を新しい視点から捉 える先端科学技術にかかわる講義が開設されている.

\section{研究室の発足}

大林研究室の祖は土木工学科設立に尽力された丸安隆 和教授であり，昭和 53 年 4 月に丸安・大林研究室が発 足した. 東京理科大学理工学部土木工学科の第 1 期生が 4 年生に進級する時期であり, 研究内容が重複すること もあってごく自然に形成された，当時，若手の助教授の 一人として民間会社加ら参加した大林の研究／教育に対 する指導方針は厳しく，今でも語り草になっている話題 は多い. 丸安教授退任の後, 大林研究室として独立した 後も㛜しさの伝統は受け継がれている. 大林研究室は本 学土木工学科で土木計画学の分野を担当する一方, 東京 理科大学リモートセンシング研究所 (所長 : 大林成行兼 務）を全面的に支援し, 数多くの研究成果をあげている.

\section{研究室の構成員}

現在の研究室は, 大林成行教授, 小島尚人助手, 江野
沢誠助手の教員 3 名亡大学院博士後期課程 1 名, 同前期 課程 (理工学研究科修士) 6 名, 理工学研究科研究生 4 名, 学部 4 年生 (卒業研究生) 9 名, さらに中国からの 留学研究生 1 名といったメンバーで構成され, 日夜研究 を続けている. なお，大学院後期博士課程 1 名は当学科 でも初めての女子学生であり, さらに学部 4 年生の中に も 1 名の女子学生が在籍している. 今後の土木の分野に おける女性の活躍が期待される。 また，現在のメンバー に加えて岡雅夫氏（現：(株) 長大), 本学科創設以来初 めての課程博士である高橋康夫氏（現：(株) 三菱総合 研究所), 平野暁彦氏 (現: 東関東道路エンジニア (株)) といった 3 名の元助手の研究成果は, 現在の研究活動の 基盤を整備したものとして特筆するものがある.

研究活動の沿革

大林研究室のこの 12 年間を振り返って見ると次の 5 つの活動期に分けられる.

第 1 期（昭和 53 年〜 54 年）: 道路，環境設計を中心 とした研究室創設期. 研究施設が不足していた時代でも あり，学外機関に卒業研究をお願いすることも多く，卒 業研究生達に多くの不便をかけた時代でもあった。

第 2 期（昭和 54 年〜 55 年）: 写真測量技術を用いた 雲高測定のために屋外作業が多く, 夜間測量や山小屋で の合宿を通して楽しい研究活動を展開した.この時期は, 現在建設分野において大きな関心事になりつつある「建 設情報支援システムの構築」に関する概念が初めて研究 テーマとして議論された記念すべき期間でもある.

第 3 期（昭和 55 年〜 59 年）：琵琶湖の研究を対象に リモートセンシングの分野に大きく傾注していく時期. 大学だけではとうてい企画／実施できない大規模な野外 調査作業が多く，社会人亡の接触を通して多くの思い出 を残した時期である. また，東京理科大学りモートセン シング研究所の設立とその育成のために膨大なソフトウ エアを開発・整備するために日夜苦悩した時期でもある.

第 4 期（昭和 59 年〜62 年）: 地域情報データベース の構築を研究の柱にしながらデータベースの研究に比重 をかけていく. 研究室の中にデータベース班, リモート センシング班といった言葉が生れた時期である．時代の 要請を受けこの頃から大学院生が急増し, 学部から大学 院までの一貫した教育研究体制が確立するようになる.

第 5 期（昭和 62 年〜現在）：リモートセンシングと データベースを融合した新しい研究領域を開きつつある 第 5 期. 第 4 期までに培われてきた研究を基盤に将来へ 向けて研究室の一層の拡充が期待される発展期である. 


\section{現在の主な研究内容}

12 年間の研究内容は, 膨大な数に及び主としてリモー トセンシングとデータベースに関係したテーマのもとに 建設情報支援システムの構築に携わってきた。 現在着手 している主な研究を以下に紹介する.

(1) 土木構造物の解体・処理を対象としたエキスパー トシステムの構築：土木構造物を効率的, 合理的に取り 壞し，さらに発生する建設廃材をどのように処分すれば よいのかといった問題に正面から取り組むものである. 近未来の社会問題の解決を支援するアプローチとして非 常に重要な課題であると認識している.

(2) パソコンを用いた画像処理/解析システムの体系 化：衛星リモートセンシングデータの普及・啓蒙を目的 にパーソナルコンピュータによる画像処理/解析システ ムを構築する研究である. 大型汎用コンピュータで蓄積 された画像処理／解析のノウハウを活かした設計思想の もと, 特別の教育を受けなくとも対話型で手軽に利用で きる汎用システムの開発を進めている. データフロー型 プロセッサを利用し，従来では数十分かかっていたクラ

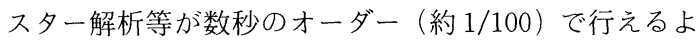
うになり，大幅な処理の高速化を実現している.

（3）地域情報データベースシステム：「地域」にかか わる情報を効率的に入力, 蓄積, 管理, 運用するための データベースシステムを構築するものである. 入力, 検 索, 表示, 編集, 維持管理といった 5 つのサブシステム 構成とし, 数百本に及ぶ膨大なプログラム群と操作マ ニュアルが整備されつつある.データ入力では 5 年に及 ぶ歳月を費やしており, 学生達の労に負うところが大き い. 研究室の財産の 1 つでもある.

(4) 道路維持管理データベースシステムの構築: 近 年, 道路網の整備に伴って道路維持管理といった問題が 注目されるようになってきた。本研究では道路維持管理 にかかわる情報を体系的に収集整理し, データベース化 するとともに効率的, 効果的に道路維持管理業務を支援 するシステムを目指している. 取り扱う工種を橋梁, 卜 ンネル, 盛土, 舗装等の 11 種類に区分し, 関係図面や 現場写真類等については画像データとしてデータベース に取り込む. 現在, EWS (Engineering Work Station) 上で稼働するシステム開発を進めており, 入力, 表示, 検索，加工／編集といったサブシステムの開発に全力を 傾注しいる．まもなく完成する予定である.

(5) EWS をベースとした GCP データベースシステ ムの構築：衛星リモートセンシングデータに内在する幾
何学的歪の補正処理に利用される地上基準点（GCP： Ground Control Point) をデータベース化し, 幾何学 的歪補正処理を効率的に行うためのシステムを構築する ものである. 大型汎用コンピュータ上で利用できるシス テムはすでに完成しており，この設計思想を受け継ぎ， EWS を用いてよりユーザフレンドリーなシステムを開 発中である. 現在までに蓄積された GCP は 3000 点以 上に及び，その利用価値は非常に高いものといえる.

(6) 建設分野におけるリモートセンシングの利用

(a) 斜面崩壊予測問題：斜面災害は局所的, 突発的に 発生し, 未然に防止, 予測することは最重要課題として 取り上げられている. 本研究では数量化理論を中核とし た斜面崩壞予測モデルの開発を進め, 崩壊危険性図を作 成できる可能性を見出している，その成果は「「斜面崩壊 予測を対象とした衛星マルチスペクトルデータの実利用 化について, 土木学会論文集, 第 415 号 /VI-12, pp. $71 \sim 80,1990$ 年 3 月」として一部発表するに至っている.

（b）土地分級評価問題：衛星データや種々の地理情報 を「土地に内在する潜在因子」として定義し, 土地利用 計画策定段階に利用できる土地分級評価主題図を作成す る支援モデル（潜在因子モデル）の開発に着手している. 基礎デー夕の収集においては国土庁, 東京都のご指導の もと，「都道府県土地分類基本調査」として伊豆七島全 島の調査を完了した．すでに大島地区では全国でも初め ての試みとして全図幅の数值情報化を提案, 印刷・刊行 するに至り，好評を得ている。このほかにもMESSR, TM, HRV デー夕等, 種類の異なる衛星デー夕の特性 比較等, 数多くの研究テーマに取り組んでいる.

おわりに

本研究室は以上の研究内容が示すとおり, 日夜コン ピュータとともに奮戦している. コンピュータとその周 辺機器については, わが国でも有数の恵まれた研究環境 にあるといえる. 対外的にも研究活動の範囲は広く, 日 本リモートセンシング学会, 土木学会, 土質工学会等, 種々の委員会の情報が絶えず研究室に伝えられ，情報は 大変豊富である. 発足当時から 3 名の工学博士, 25 名 の工学修士，100 名に近い卒業生を輩出し，200 編を越 える研究論文および研究報告書, 14 冊の著書を中心之 した研究成果が蓄積されている. 12 年間の研究室の歩 みがどのような評価をいただけるのかは不安のあるとこ ろですが，今後とも各方面の方々のご支援を賜りますよ うお願い致します. 最後に研究室紹介の機会を与えて頂 きましたこと，厚く御礼申し上げます。 